\title{
The Practice of Khul' in Germany: Pragmatism versus Conservativism
}

\author{
Mahmoud Jaraba \\ Friedrich-Alexander-Universitat Erlangen-Nurnberg \\ mahmoud_jaraba@yahoo.com
}

\begin{abstract}
In this article, I examine how Muslim women who ae religiously-married in Germany might initiate no-fault divorce in the absence of a German registered civil marriage. Because there is no Muslim state authority to consult, local imams and Islamic leaders can resort to a community-led practice known as khul'(divorce initiated by the woman) to dissolve an Islamic marriage (nikạh) that is not recognized by civil authorities. In this article, which is the culmination of three years of fieldwork in Germany, I analyze and interpret the views and practices of two groups of religious actors - conservatives and pragmatists - towards khul' in cases of nikạh. I find that conservatives only permit a woman to divorce through $k h u l$ ' with her husband's consent, whereas pragmatists use Muslim minority jurisprudence (figh al-aqalliyyāt al-Muslima) to argue that the husband's consent is not essential to legitimize a khul' pronouncement.
\end{abstract}

\section{Keywords}

Germany - religious actors - divorce - khul' - nikāh - figh al-aqalliyyāt al-muslima

\section{Introduction}

When I first encountered Amina while conducting fieldwork in southern Germany in the summer of 2013, she had been through many years of a troubled marriage. ${ }^{1}$ Her wedding took place ten years earlier at a local mosque in a small

1 Research for the first year of this project was supported by the German Research Foundation (DFG) as part of the project PROMETEE (DFG-TH1582/1-1). 
German city, but the couple did not get a civil marriage at the registry office (Standesamt). ${ }^{2}$ Throughout her marriage, which produced four children, her husband mistreated, insulted, humiliated and, at times, physically abused her. When it became clear that there would be no lasting solution to their problems despite the numerous attempts by imams and other leaders of the Muslim community to help the couple resolve their difficulties, Amina asked her husband to grant her a talāq (literally, repudiation, but in effect a unilateral divorce by the husband). In return, she offered to relinquish her right to the deferred portion of her dower (mahrmu'ajjal) and to forfeit a sum of EUR 4000 that she had lent him. Islamic legal experts might understand Amina's offer in two ways. If Amina wanted to renounce her deferred dower rather than return her already received prompt dower, legal experts might characterize it as a divorce by mutual agreement (mubāra'a). However, if one treats the waiving of the sum of EUR 4000 as compensation for her husband in exchange for his tala $q$, then the divorce would be a negotiated repudiation $(k h u l){ }^{3}$

However, Amina's husband categorically turned down her offer, insisting instead on full custody of the children. In late 2013, when I asked Amina's husband why he refused to cooperate with his wife's request to separate on the grounds of 'mutual consent,' he told me that "if she doesn't give up her right to custody (hadāana), ${ }^{4}$ I will keep her suspended forever - neither married nor divorced." ${ }^{5}$ Here, Amina's husband is using child custody as leverage in the divorce negotiations. ${ }^{6}$ This is because, while the German judiciary cannot help Amina acquire a religious divorce, the state courts do not link child custody to the marital status of the parents. Therefore, a wife can always address the state courts and file for custody of her child, whether her marriage is religious or

2 All names in this study have been anonymized to ensure privacy.

3 Two ways of divorce by agreement are traditionally distinguished by Muslim scholars: $k_{h u l}$ and mubāra'a. In khul', the husband repudiates his wife at her demand, and in return for compensation that may be some or all of her financial post-divorce rights. In mubāra'a, repudiation is by mutual consent, and each spouse waives financial obligations (Kruiniger 2015: 84-85).

4 In Islamic law, a wife who is divorced by her husband has temporary rights of custody until the child reaches a certain age. The exact age varies across the madhhabs (legal schools). See Tucker (2008: 29).

5 Amina's husband, interview with author, southern Germany, October-November 2013.

6 Many religious actors explained to me that the issue of child custody is sometimes used by husbands to pressure their wives before they agree to grant them a divorce or consent to a khul'. Husbands exploit their wives' ignorance of German state law and the fact that they do not speak German. They also rely on their wives' fear of consulting state institutions and the complex state bureaucracy. 
civil. In such cases, the court will decide the matter based on the best interest of the child. ${ }^{7}$ Clearly, Amina's husband hoped that his wife would willingly give up child custody in return for a divorce.

When Amina realized that an amicable end to her nikāh (Islamic marriage contract) was unlikely, she asked Abdullah, an Egyptian imam at the mosque where she and her husband had married, to help end her marriage by judicial khul', hoping that he would use his authority as an imam to enforce the khul'. Imam Abdullah tried to reconcile the couple, but when his efforts failed, he granted Amina a khul' divorce without her husband's consent. Under normal circumstances, khul divorces are documented. However, Imam Abdullah feared documenting Amina's khul' because he is not officially authorized to perform such a divorce. Consequently, he granted the khul' verbally without providing documentary evidence. This meant that Amina had no documentary proof of her divorce.

Fearing that the non-documented khul' would not carry any religious weight, Amina contacted an Egyptian imam named Waleed, who some people refer to as a $m u f t t^{8}$ (legal expert) and asked for help and advice. Imam Waleed, who lives in Germany, considered the non-documented khul' invalid because it lacked the husband's approval - despite the fact that in 2000 the highest religious authority in his country of origin - the Sheikh of al-Azhar in Cairo - had approved of khul' as a unilateral divorce and gave it religious legitimacy with-

7 During my fieldwork, I have come across many cases in which a husband would refuse to divorce his wife. Those cases revolve around financial disputes between the two spouses, e.g., over a house, furniture, land or the dower. While it is difficult to treat this issue comprehensively in this study, I am currently writing another article in which I attempt - among other things - to analyze the compensation that the wife pays and its conditions.

8 According to Richard Martin (2004: 478), a "mufti, or jurisconsult, stands between man and God, and issues opinions ( fatwā, pl. fatāwa or fatwās) to a petitioner (mustafti) either with regard to the laws of God or the deeds of man. In early Islam the mufti operated as a privately funded, free agent who was independent of state control." However, in many Islamic countries today, the muft $t$ is directly subject to the authority of the nation state. The German state does not, however, officially recognize a mufti. Consequently, the issue of fatwās in Germany is chaotic, and many people consider themselves to be muftīs without having been appointed to that position by any entity. In 2016, however, a Fatwa Committee was established, headed by Dr. Khaled Hanafy, who is a member of the European Council for Fatwa and Research (ECFR). The committee answers questions in both Arabic and German on religious matters faced by Muslims in Germany, including legal, medical, psychological, social, and economic matters. The committee abides by ECFR guidelines and is active on social media, including Facebook. See <http://www.fatawa.de/>. Unlike a qā ment; he provides explanation to questions that are raised to him based on an Islamic legal perspective. 
out the consent of the husband (Sonneveld 2012: 42). At present [September 2017], suspended between Imam Abdullah's non-documented khul' and Imam Waleed's invalidation of it, Amina does not know whether she is married or divorced.

In Arab Muslim communities in Germany, a woman in Amina's situation is referred to as 'suspended' (mu'allaqa), which means that, unless her husband is willing to divorce her, she cannot leave the marriage and must continue living in an unresolved situation (Quick 2008: 29-30). Recall that Amina and her husband performed a nikăh in a mosque without obtaining a civil marriage at the registry office. Such a marriage is not regarded as legal under German law: From a legal point of view, their nikăh is a voluntary act, and under German law they have no claim to the legal rights of a spouse, such as inheritance, tax benefits, and social support. More problematic, Amina cannot address a German court because, under German law, her marriage was never registered, recognized, or sanctioned (Robbers 2013: 305). Nor can she turn to a religious authority because Germany recognizes neither the Islamic judiciary nor the right of a mufti to exercise jurisdiction over marriage and divorce (Fournier and McDougall 2013: 445).

In the international legal studies literature, a woman whose divorce is recognized as legal in one country but, due to conflicting laws, not in another, is said to be in a 'limping marriage' (Cohn 1969: 577). In Europe, the term is also used to describe a person to whom a civil court has granted a divorce but who has not been granted a religious divorce (Yilmaz 2003: 131). In many cases, women are unable to remarry within their religious community unless they get a religiously-recognized divorce, even if they obtain a civil divorce. By contrast, Muslim men can re-marry without a civil or religious divorce, since polygamy is generally permitted for Muslim men in the Qur'an, with certain restrictions, though it is not officially recognized by European states (Khir 2006: 303). Studies undertaken in Britain (Keshavjee 2013), the Netherlands (see van Eijk's article in this special issue) and North America (Quick 2008, Korteweg and Selby 2012) have shown how Muslim diaspora communities in the West resort to complex, informal systems of Islamic dispute settlement in their attempts to resolve such difficulties. While drawing attention to the problem of limping marriage, these studies say little about situations such as Amina's in which there is a nikăh without a civil marriage that was registered with the relevant state authorities. Women in limping marriages can at least get a civil divorce, which some religious figures consider equivalent to a religious divorce. However, women in Amina's situation can get neither a civil nor a religious divorce. This study focuses on the debate among religious leaders such as imams and independent Muslim mediators regarding such cases in Germany. ${ }^{9}$ 
When a nikăh breaks down in Germany, the relationship can be terminated through one of two processes - țalāq, in which the husband divorces the wife and pays the deferred dower (mahr) and maintenance (nafaqa), or khul', in which the wife renounces her financial rights and pays compensation..$^{10}$ Unlike talāq, which is considered the exclusive right of the husband, Muslims often see $k_{h u l}$ ' as a way for a woman to get out of her marriage. The word khul'refers to the compensation (fidya) that a wife gives to her husband in return for his agreement to end the marriage (Tucker 2008: 95). The compensation can be a portion (or all) of the dower she received, or any other agreement she may have reached with her husband. For example, she might agree to relinquish a deferred portion of her dower.

This is the first study to examine how Muslims in Germany dissolve a nikāh when the husband refuses to grant his wife a divorce. In my fieldwork, I conducted numerous in-depth interviews and collected many khul' documents in an effort to establish how religious leaders respond to applications for femaleinitiated divorces in Germany. I found that because there is no Muslim state authority in Germany, dissolving a nikāh through khul' is a community-led exercise practiced by local imams and Islamic leaders. In this article, I discuss and analyze the views and motives of religious leaders, namely imams and mediators, who become involved in khul' cases in which couples failed to notify the civil authorities of their marriage. Those leaders fall into two groups: I call the first group "pragmatists" and the second "conservatives," (see below). While in some Muslim-majority countries, independent legal reasoning (ijtihād) is

viewpoints of the religious actors brought in to resolve these disputes. The documents I collected during my fieldwork are all khul' cases in which there was no registered civil marriage, but it is important to mention that the religious actors approached the dissolution of registered marriages in exactly the same way as they approached marriages that were not registered. This is because conservatives do not regard a civil divorce as the equivalent of a religious one. Therefore, they insist that a khul' divorce must include the husband's consent. By contrast, pragmatists, who recognize civil divorce and religious divorce as equivalent, require no further action. The subject of why some imams recognize religious and civil divorce to be equivalent and some do not is beyond the scope of this article. Suffice it to say that some imams - especially those from Turkey or Albania told me that a woman who gets a civil divorce from a state court does not need to get a religious divorce from an imam. They treat the two types of divorce as equivalent.

None of the religious actors I interviewed performed tafrī (judicial divorce) because a competent $q \bar{a} d \bar{\imath}$ (judge) must verify the grounds of a female plaintiff's request to dissolve her marriage. While no grounds are required for a woman to obtain a khul' divorce, a

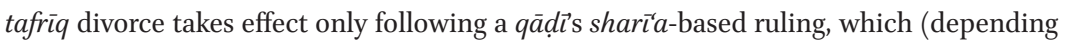
on his madhhab) may be on one of a variety of grounds, including (1) the apostasy of either spouse, (2) inability to provide maintenance, or (3) the presence of a physical impairment that prevents sexual relations or causes aversion. See Tucker (2008: 113). 
exercised to reform Islamic family law, ${ }^{11}$ in non-Muslim majority countries religious leaders practice either taqlïd (uncritical adoption of earlier opinions) or Muslim Minority Jurisprudence (fiqh al-aqalliyyāt al-Muslima, hereinafter fiqh al-aqalliyyāt). ${ }^{12}$

The term 'pragmatist' has triggered debate among those who try to define its meaning, context, and uses. In this study, I use the term to refer to religious leaders who prioritize practical considerations over the religious texts. Based on fiqh al-aqalliyyāt, they use reason to reread and reinterpret religious texts in an effort to reach solutions to social problems faced by Muslims in Germany. Pragmatists see shari' $a$ as providing flexible guidelines that they can modify to suit the circumstances of the Muslim minority in Germany, rather than as a set of fixed laws and rigid rules. In the absence of an Islamic judiciary in Germany, pragmatists maintain that local imams and other Islamic leaders are entitled to act as a Muslim judge $(q \bar{a} \underline{d} \bar{\imath})$. They argue that such religious leaders have the right to intervene and terminate the marriage, as a qā refuses to accept a khul.

Pragmatists face major challenges from two powerful Muslim groups that I together I call the "conservatives." The first group consists of conservative imams and independent arbitrators who read and interpret the Islamic texts in what I argue is both a literalist and patriarchal manner. This group is entirely male, and I argue that they read texts in this way in order to maintain the status quo and their own power and influence. The second group consists of Muslim clans $^{13}$ and families who - owing to patriarchal attitudes - see khul' as a threat to their unity and stability.

\section{Methodology and Outline}

This article is based on ethnographic fieldwork that I undertook between 2013 and 2016 in the German states of Berlin, Bavaria, North Rhine-Westphalia and Hesse. I spent more than a year in Muslim communities studying the context, practice, and dynamics of nikāh, țalāq and khul' in order to ascertain how conservative and pragmatic groups interpret and justify their respective practices and positions. For a study of this kind, it is necessary to establish relationships of trust, and so in the first year I became acquainted with a

\footnotetext{
11 See Abbasi (2017).

12 On fiqh al-aqalliyyāt, see further Zahalka (2016).

13 I use the term 'clan' here to refer to groups of people who share bonds of kinship and have a sense of shared origin, tradition, customs, accent, and culture.
} 
number of key Muslim religious leaders (imams and independent arbitrators) in Bavaria. These contacts subsequently enabled me to gain quick access to religious and independent arbitrators in the other states (Bundesländer, singular Bundesland). I used a 'snowball' sampling method in which I asked each interviewee to nominate additional contacts. ${ }^{14}$

I conducted more than one-hundred qualitative interviews in either Arabic or German with male religious leaders who, in one way or another, dealt with issues related to nikāh, țalāq and khul'. The duration of the interviews varied considerably. Some lasted for only thirty minutes, while others went on for almost three-and-a-half hours. Using a semi-structured questionnaire, I conducted the interviews on a face-to-face basis and interviewed many of the participants several times. I took detailed notes during most interviews, and I recorded some with a voice recorder, which I later transcribed. In addition, I conducted twelve interviews with women from Syria, Egypt, Morocco, Pakistan, Lebanon, Palestine and Turkey who had obtained a khul' divorce in Germany or were in the process of trying to do so. During my fieldwork in Berlin, I collected fifty-one khul' documents containing detailed information on nikăh certificates, the identity of the woman requesting the khul', her husband's and her own proposed terms for the divorce, and any agreements on dower repayments and, in some cases, child custody. ${ }^{15}$ Since my focus here is on how conservative and pragmatic groups regard $k h u l$ ', I use the interviews with women seeking khul' and the khul' documents only to clarify, illustrate, and better define and understand the positions of the religious leaders.

\section{Amina's Nikāḥ: Religiously but not Legally Binding}

Many of my interviewees informed me that Muslims in Germany get married in three different ways. The first, civil marriage, is performed and registered at a registry office without a religious ceremony; according to several of my interviewees, only a minority of Muslims choose this option. The second includes two distinct types of marriage: a civil marriage, which protects the legal rights

\footnotetext{
14 This sampling method is described by Russell Bernard (Bernard 2006).

15 During my fieldwork in Berlin, I had the opportunity to examine thousands of documents containing valuable information on terms and conditions pertaining to nikăh, talāq and khul'. I was allowed to make copies of approximately 2000 documents, including fifty-one khul' documents. These documents, which were issued by imams and private arbitrators, are currently stored at the University of Erlangen-Nuremberg and will be destroyed upon completion of the study.
} 
of both parties, and an Islamic marriage, nikăh, which might take place at a mosque or under the supervision of a Muslim scholar or an independent arbitrator. My interviewees told me that the largest and most diverse group of Muslims selects this option. The third option, chosen by couples like Amina and her husband, is nikāh without a civil marriage. ${ }^{16}$ There is little official statistical data on the frequency of nikăh in Germany, and the imams I interviewed all provided different estimates. For example, Mamdouh, a Palestinian imam in Berlin, estimated that in the Arab community in Berlin approximately 70 percent of all marriages are nikāh without civil marriages, ${ }^{17}$ while Anas, a Tunisian imam, put the number of Arabs who marry only by nikāh at approximately $5^{0}$ percent. ${ }^{18}$ Imams from the Turkish community opined that in their community between 20 and 30 percent of all marriages are nikăh..$^{19}$ Abdulkader, an Egyptian imam attached to an Islamic centre in southern Germany, believes that, in light of the growing number of Muslim refugees now entering the country from conflict zones in Syria, Iraq, and Afghanistan, the percentage of nikăh marriages is likely to increase. Like many of the imams I interviewed, he believes that these people will find it difficult to obtain the identity documents they need to register civil marriages. ${ }^{20}$ In addition, in Syria (Carlisle 2008: 5974; Van Eijk 2016: 168), Iraq (USAID 2014: 19), and Afghanistan (Rastin-Tehrani and Yassari 2012: 52), unregistered marriages are common, and migrants from those countries may follow the norms of their home countries when they marry in Germany.

In Germany, only the first two types of marriage are recognized by the state, for the civil marriage common to both takes place in the presence of a civil servant. The third type, which takes place in a mosque and is performed by a religious figure, is not recognized by the state, and therefore has no legal standing. By contrast, some European countries, like England and Spain, recognize a religious marriage if it is performed in the presence of an authorized civil servant and registered with civil authorities. ${ }^{21}$

Until 2009, it was illegal under German law to perform a religious marriage prior to a civil one. In January of that year, the government amended the law of

16 Some couples choose to have an Islamic marriage without having a registered civil marriage, for reasons that fall outside the scope of this study (e.g., insufficient documentation, religious preference, a shortage of money, cultural bias and lack of information about civil marriage).

17 Imam Mamdouh, interview with author, Berlin, April 2015.

18 Imam Anas, interview with author, Berlin, June 2015.

19 Imam Galip, interview with author, Berlin, April 2015.

20 Imam Abdulkader, interview with author, southern Germany, December 2015.

21 On marriage laws in Britain, see Probert (2011). 
civil status (Personenstandsgesetz) to allow couples to hold their religious ceremonies first (Robbers 2013: 305). However, the amendment did not alter the fact that the German legal system recognizes only a civil marriage. In Germany, "there is no system of personal laws based on religious affiliation. The state legal system is wholly secular. Religious activities are protected, but there is no part of the law which adopts religious rules as a source of law" (Ino Augsberg and Stefan Korioth 2016: 180).

\section{Dispute Resolution by non-State Processes: Religious Leaders and Mechanisms}

Numerous imams and other religious leaders in Germany have told me that a nikạ $h$ that fulfils the Islamic legal requirements is a legitimate and socially acceptable marriage. Nevertheless, German courts do not recognize nikăh, and from a religious standpoint a woman who has a nikạh marriage is unable to remarry if she does not get a divorce.

A woman like Amina, who has only a nikăh and seeks khul', cannot apply to a German court, and her only options are non-state mediation (wisāta) or arbitration (tahkim) by imams and Muslim leaders. Comparing Germany to Britain highlights the difficulties facing Amina and other Muslim women in Germany. In Britain, sharīa councils "operate as unofficial legal bodies specializing in providing advice and assistance to Muslim communities on Muslim family law matters" (Bano 2008: 295). While it is true that the British sharīa councils are unofficial, they are well-organized and follow a formalized standard procedure. ${ }^{22}$ Bowen observes, "They provide downloadable forms on their websites, charge set fees for service, and meet on scheduled days of the month" (2012: 159). Muslims can easily find such councils in London, Birmingham, Manchester or Bradford. By contrast, Muslim mediation and arbitration in Germany are informal, unregulated, usually take place behind closed doors. ${ }^{23}$ There is no state or judicial recognition or regulation of any form of Muslim mediation or arbitration. ${ }^{24}$

In Germany, numerous religious leaders observe sharī'a norms and engage in settling private, religious, economic, or social conflicts through mediation or arbitration; they handle family disputes and issue nikāh, talāq, and khul'certificates. To demonstrate their respect for religious norms, they try to base their

\footnotetext{
22 On sharīa councils institution and internal procedures, see Bowen (2016: chapter 5).

23 On sharīa councils and legal pluralism in Britain, see Manea (2016).

24 On non-state alternative dispuite resolution, see Woodman (1991: 17).
} 
decisions on Qur'an and sunna. It was apparent from the people I interviewed, as well as from my own observations, that many such religious leaders enjoy considerable popular respect and reverence in their communities and, therefore, wield considerable influence over mediation and arbitration procedures. They easily and effectively establish rapport with the grassroots and the poor. In addition, they utilize their wide social and religious influence to persuade the litigants to compromise with one another and to reach an agreement. In most cases, the litigants, especially if they are pious and observant, see them as acceptable players in the mediation process.

It is important to distinguish between two groups of religious leaders imams, on the one hand, and independent mediators (wasit, pl. wusațā') and arbitrators (muhakkam, pl. muhakkamün), on the other. These two groups serve between 4.4 and 4.7 million Muslims (5.4-5.7 percent of the 82.2 million inhabitants of Germany), of whom more than half ( $5^{1}$ percent) have Turkish roots (Stichs 2016: 5 ). In addition to Turks, the Muslim community includes Arabs, Kurds, Albanians, Pakistanis, and Iranians.

Imams are the most important religious leaders. Among Sunni Muslims, an imam's primary responsibility is to lead the prayer service. He also acts as a community leader, serves as a consultant on spiritual, religious or private matters, and commands considerable respect from members of the Muslim communities. ${ }^{25}$ There are approximately 2,500 mosques and prayer rooms across Germany (Rohe 2008: 53) in which approximately 2,000 imams are employed to carry out a range of duties. ${ }^{26}$ The imams in these mosques adhere to their institution's instructions and guidelines on matters concerning marriage and divorce. In some mosques, the boards of directors allow the imams to proffer advice on problems associated with nikāh, talāq, or khul', while in others, they do not; a non-compliant imam runs the risk of dismissal.

In addition to performing the prayer service, many of these imams are involved in other aspects of Muslim life, including family disputes. Walid, an administrator at a Berlin Arab community mosque, estimates that at his mosque, the imam spends approximately 80 percent of his time on mediation and solving social problems, and only about 20 percent on the prayer service (Rohe and Jaraba 2015: 107). In fact, many mosques are now setting up family dispute committees, comprised of an imam and two to four eminent members of the

25 The religious and social duties of imams are discussed in Kamp (2008).

26 German Islam Conference, 'Who preaches Islam in Germany?', 6 November 2009 <http:// www.deutsche-islam-konferenz.de/DIK/EN/DIK/StandpunkteEgebnisse/Personal/Imame Theologie/ZahlenDatenFakten/ zahlen-daten-fakten-node.html> (last accessed 30 March 2017). 
mosque community. These committees are usually called 'social work' or 'family reconciliation' committees, and their purpose is to oversee Islamic marriages and divorces and to resolve family disputes. According to my respondents, as well as from what I have witnessed, these committees never include women, although women form the overwhelming majority of those who seek their help.

Imams are not the only religious leaders who play a crucial role in settling family disputes. A second group of religious leaders includes independent mediators and arbitrators who are self-appointed and, in most cases, operate independently of mosques or prayer rooms. They are not imams in the traditional sense of the word because they do not study sharîa at university level and do not lead prayers in mosques. Rather, they are individuals who sometimes take on the role of a 'Muslim judge' ( $q \bar{a} \bar{d} \bar{\imath}$ ) to solve a family conflict or decide on issues related to nikăh, talāq, and khul'. It is difficult to estimate their numbers, but it is safe to say that they are present in several German cities, including Berlin, Nuremberg, Hamburg and Frankfurt. Many of the divorce and khul documents I obtained during my fieldwork were signed and stamped by a selfappointed $q \bar{a} d \bar{l}$ who had no formal authority or qualifications. In fact, none of

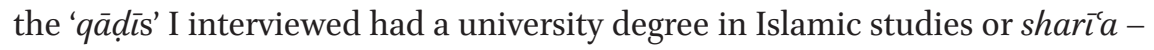
or knowledge of German law, for that matter.

\section{Attitudes Toward khul}

Although the sample is not representative of all religious leaders in Germany, it does include the major Muslim communities, namely, Turks, Arabs, Bosnians, Albanians, Pakistanis, Mhallamis, ${ }^{27}$ and Kurds. I interviewed 103 religious leaders - fifty-five imams and forty-eight independent arbitrators - all of whom were male. Of these, forty-eight had a university certificate in $\operatorname{sharit}^{i} a$, sixteen had a university degree in either sociology, psychology, or law, and six were engineers; nearly a third (thirty-three) had only high school certificates. Despite numerous attempts, I failed to find a female religious actor who participated in khul'negotiations or family dispute resolution.

The attitudes of religious leaders towards khul' and its procedures differ markedly. For example, 43 percent of my respondents (sixteen imams and

27 Mhallamis are a group of Kurds who emigrated from Mardin, Turkey, to Lebanon between 1925 and 196o. In the aftermath of the Lebanese civil war (1975-1990), many of them migrated to Germany and settled down in Berlin, Bremen, and Essen. On the Mhallamis and their their socio-economic situation in Berlin, see Jaraba (2016). 
twenty-eight independent arbitrators) said that they refuse to get involved in khul'. Fifteen were Turkish, while six were from Bosnia-Herzegovina or Albania. Their attitude cannot be explained by the juristic opinions of the Hanafi madhhab (legal school) that is predominant in their home countries, since that madhhab allows for khul', on the condition that both the husband and the wife give their consent. A better explanation for their attitude is the influence of secular laws that are predominant in their home countries. State laws in Turkey, Albania, and Bosnia-Herzegovina permit female-instigated divorce. Sharía plays no role in these countries' national legal systems, and civil laws guarantee men and women equal rights in marriage and divorce. The 2002 Civil Code in Turkey, for instance, "makes no distinction between the grounds on which men and women may obtain a divorce ... in such a system there is no mention of khul" (Khir 2006: 299). In other words, women and men in these countries may terminate their marriage by filing a lawsuit in the civil courts; there is no need for khul'. Neither a man nor a woman needs the permission of the other spouse to initiate and obtain a divorce. A number of Turkish imams told me that they follow Turkish marriage and divorce laws, and that the informal nikāh and talāq procedures applied in mosques in Germany are in conflict with those laws. As many of the Turkish imams in Germany are official employees of the Turkish state and are paid by the Turkish Directorate of Religious Affairs (Diyanet), it becomes clear that they may fear losing their jobs if they violate Turkish law. In 2015, one of the Turkish imams told me that he does not get involved in marriage and divorce procedures in Germany out of fear of the Turkish government, not the German government. ${ }^{28}$

Turkish religious leaders in Germany are also reluctant to practice judicial khul' for fear of causing tension between mosques and the local community. This is because mosques depend heavily on funding and donations from Muslim community members, and their leaders fear that any conflicts with their members may jeopardize their funding and threaten their legitimacy. A Turkish imam informed me that he wants to avoid having men in his community accuse him of "encouraging women to revolt against them." ${ }^{29}$ Creating problems within the Muslim community might lead some people to boycott mosques and disrupt the flow of financial resources to the mosques and their influence within the community. Additionally, social considerations may deter Turkish imams from getting involved in khul', for example, an increase in divorce rates may lead to family breakdown and cause harm to children. ${ }^{30}$

28 Imam Salah, interview with author, Berlin, June 2015.

29 Imam Ibrahim, interview with author, Berlin, June 2015.

30 Although here I discuss the reasons why Turkish imams refuse to engage in khul', I found similar concerns among imams from other countries. 
The other religious leaders who refrained from performing khul' include nine Palestinians, five Mhallamis from Lebanon, three Jordanians, three Syrians, two German converts to Islam, and one Pakistani. With the exception of the German converts, they were all from countries in which sharía plays an important role in legislation and where khul' is practiced, either as a divorce by mutual consent or at the instigation of women without the consent of their husbands (Sonneveld and Stiles 2016). Their refusal to deal with khul' cases may be attributed to a number of factors. First, some of them believe that khulc conflicts with, and violates, German laws on family, marriage, and divorce. Second, some religious leaders recognize an (Islamic) marriage only if it is registered with the appropriate state authority and they believe that a civil divorce offers sufficient grounds for terminating a marriage, thereby obviating any need for a religiously sanctioned procedure. Third, other imams and independent arbitrators assert that practicing khul' in the absence of an officially recognized $q \bar{a} q_{\bar{l}}$, whose decisions are binding, would exacerbate social conflict, particularly if one party challenges or refuses to adhere to the decision. Finally, some respondents said that they lack any expertise in khul'; in other words, they knew too little about it or its usage. I have excluded this group - the group that refrains from khul' - from my analysis, both because its members decline to engage in khul' and because they gave me insufficient information to categorize them as either conservative or pragmatic.

Approximately 57 percent of the respondents (forty imams and nineteen independent arbitrators) comprised the second group: those who are willing to engage in $k h u l$ '-related matters. More than one-third (twenty-three) of the group was Egyptian. In addition there were twelve Palestinians, five Moroccans, four Syrians, three Mhallamis, three Tunisians, three Pakistanis, two Yemenis, two second-generation Muslims, one Algerian, and one German convert. This group of fifty-nine religious leaders provides the basis for the following discussion and analysis. I classified only ten members of this group as pragmatists: These leaders were willing to invoke figh al-aqalliyyāt in order to grant a woman a khul' divorce even without her husband's consent. I classified forty-nine of the fifty-nine (83 percent) as conservatives because of their refusal to modify Islamic religious laws to accommodate the life circumstances of Muslims in Germany and, therefore, grant a woman a khul' divorce without her husband's consent.

Of the ten pragmatists, six have no university degree and four have humanities degrees. ${ }^{31}$ None has studied sharĩ $a$. Seven are imams, while three described themselves as independent actors. This means that individuals who have never formally studied or specialized in sharīa subjects are reinterpreting sharī $a$. For 
this reason, they regularly turn to recognized authorities overseas for consultation and rulings on points of Islamic law (see below).

Of the forty-nine conservatives, slightly more than two-thirds (thirty-four) have studied sharía, most of them at al-Azhar University in Egypt. ${ }^{32}$ The remaining fifteen conservatives include five engineers, two men with a background in the humanities, and eight with no university degree. More than two-thirds of the respondents in the conservative group (thirty-three) are imams, while sixteen are independent arbitrators.

\section{Khul' in Germany: Mutual Consent Versus Litigation}

Muslim scholars disagree over whether a husband's approval is needed to validate a khul' divorce - in other words, can a qã dī force a husband to accept compensation in return for agreeing to khul'? According to Khir, "very few jurists have taken the view that $k h u l^{\text {'c }}$ can ... be decided [only] in a court, and the majority, including Mālik, al-Shāfíī and [Ibn] Hanbal, allow it with or without the intervention of a judge" (2006: 298).

For religious leaders in Germany, forcing Amina's husband to divorce his wife is a point of contention. The majority of Muslim scholars and the four Sunni schools of Islamic law agree that khul' requires mutual agreement between husband and wife. According to Nadia Sonneveld, "the four Sunni schools of Islamic law know only a consensual form of khul divorce," which means that "a woman can take the initiative to request a divorce from her husband, but she still cannot obtain it without his permission" (Sonneveld 2012: 12). If a husband refuses to accept his wife's request for khul', Muslim scholars disagree about whether the judge has the right to terminate the marriage contract (Tucker 2008: 99). Despite this disagreement, the state laws pertaining to personal status in some Muslim countries, including Egypt (Sonneveld 2012) and Pakistan (Ifzal and Farooq 2014), have been reformed and women are now

32 It is interesting to note that in 2000, when the Egyptian parliament was embroiled in a heated debate over $k h u l^{\prime}$ as a female unilateral divorce, the Sheikh of al-Azhar declared in front of Parliament that this form of khul' is religiously valid (Sonneveld 2012: 42). In 2012, al-Azhar's Academy for Islamic Research rejected a demand by some members of Parliament to revoke the khul'law (Sonneveld and Lindbekk 2015: 16). Why did conservatives in Germany take a position on $k h u l$ ' that goes against al-Azhar? It is possible that they came to Germany before the Egyptian law was enacted in 2000. Or perhaps they opposed the Egyptian law. Al-Azhar as an institution supports the law, but some of its scholars do not (Sonneveld 2012). A third possibility is that those imams might not respect and adhere to al-Azhar's authority and decisions. 
able to submit a complaint to the judge. In these countries, a judge has the right to terminate a marriage contract through khul', even if the husband refuses to accept the decision.

My research shows that the personal views and practices of religious leaders directly influence their approaches to khul'. Although all the religious leaders I interviewed for this study recognized the legitimacy of khul' and cited Qur'anic verses and Prophetic hadiths to support their claims, they disagreed over whether the husband's approval (muwäfaqa) is a prerequisite for it to take effect. Thus, the German Muslim community faces a number of questions: Does khul' require the mutual consent (khul' bil'-tarādī) of both the husband and the wife, and their agreement on a specific monetary amount that the wife returns? And in cases in which the husband refuses the khul', does she have the right to what imams in Germany call khul'-by-litigation (khul' bi'l-taqā which an imam, acting as a $q \bar{a} d \bar{l}$, urges the husband to accept the khul? If khul' is based on litigation, how do Muslims deal with the fact that imams are neither qū $\bar{a} \bar{t}$ (judges) nor arbitrators, and are not authorized by German courts to perform such a procedure? What, then, is the solution to this problem?

\section{Muslim Minority Jurisprudence: the Pragmatic Group}

According to Zahalka (2016:4), a $q \bar{a} d \bar{l} \bar{l}$ (judge) of the sharīa Court of Jerusalem, the concept of figh al-aqalliyyāt (Muslim Minority Jurisprudence) has been developing over the last two decades to provide:

a religious solution for Muslim minorities, mainly in the West, taking into account their distinctive life predicaments ... This is performed by altering sharica laws according to a religious methodology that is rooted in Islam and uṣul al-fiqh, the principles of religion that stipulate the terms and conditions by which new decrees can be passed.

Zahalka explains that figh al-aqalliyya at was founded on the principle of the universality of Islam, which addresses all people at all times and places by adapting its rules to change over time and place, and seeks to ease difficulty for Muslims. He points out that figh al-aqalliyyāt addresses concerns such as naturalization in non-Muslim countries, haläl food, and Islamic marriage and divorce that earlier generations of jurists did not encounter, and thus did not address in their legal works (Zahalka 2016: 3-4).

In Germany, some pragmatic imams and Muslim leaders are familiar with and apply figh al-aqalliyyatt. Anas, a local imam in Berlin, explained to me that 
fiqh al-aqalliyyāt deals with "Islamic fiqh [jurisprudence] laws relevant to Muslims living in the West as a minority group" for which the traditional sources provide no clear answers. Imam Anas explained that although religious scriptures are fixed and not subject to change, applying the scriptures to the situation on the ground "is subject to change according to place and time and is considered the result of a human effort." He adds that fiqh rulings that were appropriate for medieval Muslims may no longer be relevant. Similarly, fiqh law practiced in Malaysia or Turkey may differ from figh law practiced in Africa or the Arabian Peninsula. According to Imam Anas, Muslims in the West "need jurisprudence that suits their situation as a Muslim minority living among a non-Muslim majority."33

As noted, only ten imams and religious leaders in my sample recognize and employ fiqh al-aqalliyyāt to redefine and reformulate the practice of Islamic law in the West. These pragmatists do not regard themselves as being bound to any particular madhhab and use opinions from all Islamic legal schools. As one of the pragmatic imams explained to me, Muslims in the West belong to different madhhabs, not just one. As such, applying only one madhhab will make it difficult to apply Islamic law in a way that meets the needs of all Muslims. Therefore, he argues, one must utilize the different madhhabs and take from them what best suits life in Germany, and one must tailor the content of the different madhhabs to the German context. "The imam should not confine himself to only one madhhab."

Consider, for example, the position of the Palestinian Imam Belal, with whom I talked in Berlin in February 2015, on the subject of a woman marrying without her guardian's consent.

Marriage without the consent of the [woman's] guardian is a big problem for many women in Germany. There are many women whose guardian either is not present or refuses to allow her to get married. This problem is most common among second- and third-generation Muslim youth (born in Germany). What to do then, to deal with such a problem? If the woman insists on marrying that man even after I clarify the social risks that she runs, I do the nikāh procedures based on Abū Hanīfa's madhhab, may Allah have mercy on him, for he does not view the guardian's consent as a prerequisite for the validity of the nikāh.

I have also met other imams who follow the madhhabs of al-Shāfi 'ì, Ibn Hanbal, and Mālik, and who consider the guardian's consent to be one of the precondition of a valid marriage.

33 Imam Anas, interview with author, Berlin, April 2015. 
The pragmatic religious leaders typically do not have solid knowledge about sharīa or ușül al-figh. This is because, as noted, none of the pragmatists has a degree in sharīa or Islamic studies. Thus, they utilize and accept the fatwās of the European Council for Fatwa and Research (ECFR) and other fatwā institutions without necessarily understanding their scriptural basis, and then try to apply them in a way that suits the context in Germany. As one pragmatic imam in Berlin explained, he does not consider himself a religious scholar, nor does he seek to "issue fatwās." Rather, his goal is to "apply them [the fatwās] to the context of German life." Put differently: he accepts the fatwās and applies them because of the need for such legal opinions, and because of the lack of a qualified mujtahid (a scholar qualified to offer legal opinions derived from scripture), especially with regard to marriage and divorce.

Pragmatists hold that, in principle, a husband should accept khul' when a wife requests it. However, in cases in which a husband refuses to reach an agreement with his wife, they hold that a qã dì should be allowed to grant a divorce with or without the husband's consent. As Talha, a Palestinian imam in North Rhine-Westphalia, explains, the Prophet Muhammad did not serve as a $q \bar{a} d_{\bar{\imath}}$ in the case of Habiba bint Sahl, ${ }^{34}$ but he would have played that role and forced the husband to divorce her, had the husband refused to divorce her. ${ }^{35}$

Pragmatists base their arguments on Qur'anic verses and hadith reports that articulate the principles of justice and equality between men and women. For instance, Imam Anas contends that the Qur'an affords equal status to men and women, citing Q 2:228 ${ }^{36}$ as "the pinnacle of Islamic equality between men and women in terms of having equal rights and responsibilities, [including] equal rights to divorce by khul." He adds that Islam orders men "clearly and decisively not to put women in a difficult position and gives men and women equal rights to decide their destiny through divorce." Imam Anas cites the story of Habïba bint Sahl and Q 4:19, which addresses the question of placing women in a difficult position. This verse reads:

O believers, you are not allowed to take perforce the women (of dead relatives) into your heritage, or tyrannise over them in order to deprive them of what you have given them, unless they are guilty of open adultery. Live with them with tolerance and justice even if you do not care for

34 In this case, the Prophet Muhammad suggested that Ḥabiba return the garden she had received from her husband as mahr (dower) in exchange for a divorce.

35 Imam Talha, interview with author, North Rhine-Westphalia, January 2016.

36 Q 2:228 states: "Women also have recognised rights as men have". This, and all subsequent Qur'anic verses are taken from the translation of Ahmed Ali (1993). 
them. For it may well be you may not like a thing, yet God may have endued it with much goodness.

According to Anas, marriage is a contract based on mutual consent and a wife should not be forced to remain in it against her will. ${ }^{37}$ In practice, pragmatists try to adapt classical Islamic law to fit the prevailing circumstances in Germany. In other words, to keep pace with social developments in the West, they argue that they need to adopt a flexible approach in their interpretations of the Qur'an and sunna. They consider it neither fair nor reasonable to force a wife to choose between an unhappy life, possibly marred by violence, and lingering in a state of uncertainty. According to Imam Anas, even in the absence of a functioning Islamic judicial system, individuals have rights and imams must sometimes take on the role of a qādi to protect those rights. In certain cases, he argues, it is necessary to dispense with the husband's agreement to the divorce, especially "if he chooses to put the wife in a state of uncertainty." Nonetheless, the absence of a qā $\bar{l}_{\bar{\imath}}$ in Germany with the authority to order a husband to obey a decision that an imam has taken clearly makes this issue more complicated. 38

Because Germany recognizes neither nikāh nor an Islamic divorce pronounced by an imam, pragmatists utilize ECFR fatwās and those issued by individual Muslim scholars to support their positions. For instance, in 2010, at its twentieth meeting in Istanbul, Turkey, ECFR issued a fatwa to resolve the question of whether or not a qā as follows:

The council has examined the issue of whether or not a $q \bar{a} d \underline{\imath}$ should be allowed to force a Muslim husband living in the West to agree to a khul against his will. After discussing the matter, the council has decided the following:

If the aggrieved woman addresses a sharî́a judiciary council in Europe to demand khul' from her husband, the qā $\bar{\imath} \bar{l}$ must have the right to compel the husband to accept monetary compensation and divorce his wife if there is proof that the wife has been aggrieved. However, the $q \bar{a}$ di $\bar{\imath}$ must first exhaust the following procedure: First, the qādi must instruct both the wife and husband to produce at least one family

37 Imam Anas, interview with author, Berlin, June 2015.

38 Imam Anas, interview with author, Berlin, April 2015. 
member to help the couple try to reconcile their differences, or the $q \bar{a} d \bar{\imath}$ himself may carry out the reconciliation process in an attempt to save the marriage. Second, if the $q \bar{a} d \bar{\imath}$ fails to effect a reconciliation, he should try to persuade the husband to divorce the wife himself or accept the khul'. Third, if the husband obstinately refuses to accept the $k h u l$ ', the $q \bar{a} d \bar{\imath}$ should pass a ruling to separate the spouses in order to protect the wife from further harm. ${ }^{39}$

In addition, pragmatists also refer to fatwās issued by individual Muslim scholars. For instance, a number of the imams I interviewed had consulted the prominent Muslim authority, Sheikh Abdullah Bin Bayyah, who adopts and promotes figh al-aqalliyyät and has a website on which he posts his rulings on points of Islamic law. ${ }^{40}$ In one of Sheikh Bin Bayyah's rulings, he states that, since there is no Muslim qā $\bar{d} \bar{\imath}$ in the West:

Islamic centres may be granted enough authority to resolve disputes among Muslims, with the Muslim community taking on the role of a $q \bar{a} d \bar{l}$. This is because the $q \bar{a} d \bar{\imath}$ represents the Muslim community; there is no reason the community should not represent itself when there is no $q \bar{a} d \bar{l}$. Muslim scholars have said that the Muslim community takes the place of the $q \bar{a} d \underline{\imath}$ when none is present and, in rare situations, even when a $q \bar{a} d \bar{\imath}$ is present. ${ }^{41}$

On his website, Bin Bayyah justified his position on the grounds that, since Muslim minorities are required to live under non-Muslim laws, Muslims must adjust Islamic law and interpret it in light of the fundamental aims of the sharīa (maqāsid al-sharīa) ${ }^{42}$

Based on these fatwās, Imam Raed, who lives in North Rhine-Westphalia, argues that in the absence of a Muslim qā $\bar{\imath} \bar{l}$, knowledgeable or fair Muslim

39 My translation from Arabic to English of "Whether or not a Qqậlı should Force Husbands to Accept a Khul." Accessed o7 November 2016 <https://goo.gl/rfZTLG>.

40 Abdullah bin Bayyah is a prominent Mauritanian professor of Islamic studies at the King Abdul Aziz University in Saudi Arabia and a member of several international legal bodies, including the European Council of Legal Opinion and the International Association of Muslim Scholars. He specializes in Maliki law.

41 My translation from Arabic to English. Abdullah Bin Bayyah, "Muslim Community Plays Role of Judge." Accessed 22 January 2016 <http://www.binbayyah.net/portal/research/ 144>.

Abdullah Bin Bayyah, "Muslim Community Plays Role of Judge." 
community leaders may assume the role of a $q \bar{a} d \bar{\imath}$, even if they have no mandate to do so from either the German state or the Muslim community. The fatwās issued by the ECFR and by Bin Bayyah have played a significant role in shaping the pragmatists' position, encouraging them to redefine their position on khul'.

Although pragmatic imams will invoke fiqh al-aqalliyyāt to implement a judicial khul' divorce without the husband's approval, they issue such a divorce only under specific circumstances, such as the husband's disappearance or deportation from Germany. ${ }^{43}$ This is because imams and Muslim institutions have neither the power nor the authority to enforce their decisions, and because the imams fear a negative reaction from husbands in cases in which they are present. Tawfeeq, an Egyptian imam, states that the German state "has not mandated any mosque or Islamic institution to conduct activities related to nikāh, talāq or khul'." ${ }^{4}$ Imam Bakr, a Palestinian living in Berlin, claims that implementing a judicial $k h u l$ ' "may violate German laws regulating civil status, particularly marriage, divorce and child-custody related matters." According to Imam Bakr, the German public, journalists, and politicians may misunderstand or misinterpret khul' procedures as "running parallel to the German state's authority" 45 He believes this might exacerbate the stigmatization of Muslims and increase support for anti-Muslim far-right movements. ${ }^{46}$

While German laws explicitly prohibit women who want a divorce from seeking legal redress outside the official court system, the situation remains unclear if the marriage is unregistered. As noted, German courts recognize only registered marriages, but they do not interfere when an unregistered marriage breaks down. This has led a number of pragmatist imams to consider establishing a family counselling and arbitration service in Berlin along the lines of the shari $a$ council in Britain. The proposed body would include a number of imams, and the aim would be to support the position of those imams during mediation and arbitration. According to Imam Anas, the new body would focus on settling family disputes and dealing with issues relating to Islamic divorce, especially khul:

43 Of the fifty-one khul' documents I gathered, only nine were implemented without the husband's agreement, either because he was blackmailing his wife or because he had been deported from Germany.

44 Imam Tawfeeq, interview with author, Berlin, June 2015.

45 For the past five years, there has been a debate in Germany over what is called "Paralleljustiz" (parallel justice): Some academics, politicians, and journalists have accused Muslims of establishing a judicial system parallel to (and conflicting with) German legal system based on Islamic sharîa. On this issue, see Jaraba (2016).

46 Imam Bakr, interview with author, Berlin, June 2015. 


\section{Opposing Judicial Khul': the Conservatives}

Conservatives refuse to use figh al-aqalliyyāt to reinterpret religious texts in a way that would address the needs of the Muslim minority in Germany. They prefer to adhere to the teachings of the four schools of Sunni jurisprudence, a process which is called taqlid. They base their position on two arguments. ${ }^{47}$ First, they argue that Islam is suitable for all places and times, and that, therefore, its rules do not need to change with place and time. Second, they highlight the importance of maintaining social structures and patriarchal systems.

According to Waleed, the eminent German-based Egyptian scholar (muftī) who informed Amina of the invalidity of the non-documented khul'statement, a husband's approval is necessary for a khul' to take effect. ${ }^{48}$ In his view, unless both the husband and the wife agree to the divorce, and the wife returns the immediate dower and renounces the deferred dower, the khul' is invalid: "If the husband does not approve the khul', the wife has no choice but patience." Thus, a wife is at the mercy of her husband, who can leave her in an uncertain position for a prolonged period during which she is not able to obtain a divorce or, if she wishes, to remarry.

Waleed and other conservative imams adhere to what they regard as traditional interpretations of Islamic texts, which assert that khul' must be based on the mutual consent of both husband and wife and that the wife must pay monetary compensation (fidya) to her husband. A number of imams explained to me that they only get involved in khul' cases that meet these conditions: mutual consent and a prior agreement to divorce between husband and wife. Ahmed, an Egyptian imam based in Berlin, states that the imam's role is limited to acting as a mediator during the reconciliation process and issuing the khul' certificate. He argues that no litigation is involved because the imam functions solely as a third party during the mediation process and makes no binding decisions. The wife and husband (sometimes with help from their families or friends) make the final decision on how to divide their resources and on the nature of the compensation. ${ }^{49}$

\footnotetext{
47 The interviews I conducted focused on marriage, divorce, and khul. This means that an imam categorized in my study as a conservative on khul'might not be categorized as such when it comes to other issues faced by Muslim minorities, such as haläl food or buying houses using loans for which the conservative imams might utilize figh al-aqalliyyāt.

48 See Tucker (2008: 96) on disagreements between madhhabs over the need for the husband to consent to the khulc.

49 Imam Ahmed, interview with author, Berlin, April 2015.
} 
Conservative religious leaders give four reasons for insisting on the husband's consent. First, they refer to the khul' case of Habiba bint Sahl. An Egyptian imam in North Rhine-Westphalia, Imam Hudhayfa, argues that because the Prophet was acting as an adviser (mustashār) rather than as a judge ( $q \bar{a} \underline{\imath} \bar{\imath})$, he requested rather than compelled Habība's husband to accept the garden and divorce his wife. ${ }^{50}$ It follows that judicial khul'requires the consent of the husband and that a woman needs her husband's approval for khul'. This means that a $q \bar{a} \underline{d} \bar{\imath}$ has no authority to pronounce a khul'and to separate the spouses if the husband does not agree to the khul. Conservatives harshly criticize any attempts to open the door to new practices and interpretations in light of the growing Muslim presence in Germany by using fiqh al-aqalliyyāt. One of the conservative imams considers the use of fiqh al-aqalliyyāt to grant women khul by-litigation to be "a muddying of the Islamic rulings and a violation of shari' a." Consequently, he thinks that the pragmatists are "circumventing the religion" by reinterpreting scripture, and that they are therefore "destroying the religion."

Interestingly, Imam Hudhayfa's position on the need for the husband's consent is at odds with the law in his country of origin, Egypt, where a husband's agreement to $\mathrm{khul}^{\prime}$ is no longer a legal requirement, as noted previously. Moreover, the requirement to secure a husband's prior agreement to divorce is inconsistent with the guarantee of equality between men and women in the German constitution (Art. 3 GG) and the special protection afforded to marriage and family institutions (Art. 6 GG).

Second, conservative religious leaders repeatedly portray men as more capable than women of heading a family and making decisions. This is similar to what has been argued in debates in Egypt (Al-Sharmani 2008: 10; Sonneveld 2012: 47). Women, they often told me, are "lacking in intellect" and are prone to emotional and reckless decisions when angry; by contrast, men are wise and prudent. ${ }^{51}$ For instance, Hassan, a Palestinian imam based in Berlin, argues that giving women equal rights to end their marriages would "exacerbate family problems, increase the already soaring divorce rates within the German Muslim community, destabilize children, and threaten the cohesion of the Muslim community."52 It is important to note that Imam Hassan's arguments are at odds with the views expressed by many others I have interviewed, including divorced women, social workers, and some other imams. Among my interviewees, it was clear that the overwhelming majority sought khul' only as

50 Imam Hudhayfa, interview with author, Berlin, April 2015.

$5^{1} \quad$ Nadia Sonneveld (2012: Chapter 2) reported hearing similar arguments after unilateral khul'was introduced in Egypt in 2000. 
a last resort after having despaired that their husbands would desist from destructive behaviour such as drug abuse, spousal cruelty, and extramarital affairs. In fact, several of the khul' documents I collected contain information indicating that some wives tried very hard, albeit to no avail, to protect their families and to change their husbands' behaviour. Nine of the fifty-one documents contain explicit evidence of a husband inflicting physical abuse or harsh treatment on his wife prior to the khul' request. ${ }^{53}$ In four cases, violence, imprisonment, drug abuse, and drug dealing were cited as the main reasons for seeking khul'. In the remaining five cases, the husbands were keeping their wives in the marriage against their will in an attempt to force them to waive their claims to child custody or alimony payments. One document describes a husband who insisted that his wife waive all her rights before a lawyer in exchange for khul'; after she had agreed to those terms, however, he changed his mind and refused to divorce her.

Third, conservatives argue that granting women equal rights to divorce through khul'violates the Islamic principle of husband's authority (qiwāma), which imposes financial and social constraints on a wife and limits her independence. In other words, conservative imams support a marital arrangement that limits the role of the woman to that of a caretaker for her husband and children. As Belal, an Egyptian imam in Berlin, put it, "We [Muslims] respect women and see that their role is to have children and raise them... Why do the Germans want of us more than that?! German women do not want to procreate and our women are performing this role.... Muslim women have a great role in the creation of a family and raising children."

Finally, conservatives hold that even if it were possible to validate a khul without the husband's consent, no qā $d \bar{\imath}$ in Germany has the power to force a man to divorce his wife. In addition, they argue, imams are not authorized to take on the role of a $q \bar{a} \bar{d} \bar{\imath}$ to secure a khul' for a woman, as seen in Imam Ahmed's comments above. However, as noted earlier, pragmatic imams oppose this reasoning because they believe that it is wrong to disregard the rights of Muslims merely because of the absence of a traditional Islamic judiciary $\left(q a d \bar{a}^{\prime}\right)$. Consequently, they reinterpret the religious texts in an attempt to find solutions to situations in which women are trapped in a religious marriage.

\section{The Patriarchal System}

Pragmatists are challenged not only by conservative imams and arbitrators but also by some conservative clans and families. Some groups, particularly sections of the Mhallami community, strongly oppose judicial khul', which they

53 The other forty-two of the fifty-one documents contain no information on the grounds for filing for the divorce. 
see as a threat to their patriarchal clan cultures. For example, Abul al-Abd, a Mhallami community leader in Berlin, fears that giving wives a right to unilateral $k h u l$ ' would threaten the social structure and lead to "a revolution by women against customs and traditions," which, he feels, might bring about the disintegration of the Mhallami community's social and clan structure. ${ }^{54}$ During my fieldwork, tension between Mhallami community and some pragmatist imams was clearly the rule rather than an exception. Abu Jasser, a Mhallami community leader in Berlin, threatened to close down one of the biggest mosques in the city after an imam attached to it granted a khul' to a woman from his clan without obtaining the approval of either the husband or the clan. According to Abu Jasser, nikāh and țalāq are internal matters that should be dealt with only by his clan without interference from either a mosque or the state. Only the clan elders can decide whether a husband should divorce his wife and, Abu Jasser asserted, it is not permissible to "encourage women to revolt" against clan customs and traditions. ${ }^{55}$ In fact, some imams have been subjected to physical attacks: Imam Anas, for example, was brutally beaten by an angry husband after awarding a khul' divorce to his wife. I was also told that many other imams have received death threats or had their reputations ruined. In other words, granting a judicial khul' can be a threat to imams and mosques alike.

\section{Conclusion}

In January 2000, the Egyptian legislature introduced the option of a judicial khul', which enables a wife to obtain a divorce without the permission of her husband and without establishing fault on his part (Welchman 2007: 112-113; see also Sonneveld 2012). Other Arab countries have followed Egypt's lead. In 2001 Temporary Law 82/2001, passed in Jordan, includes a provision that mirrors the Egyptian provision of 2000 on judicial khul (Welchman 2007: 116). Shortly thereafter, Algeria, the United Arab Emirates, Palestine, and Qatar, legalized judicial $k h u l^{c}$, although their laws differed from the Egyptian model (Welchman 2007: 119).

In contrast to these Muslim-majority countries that now permit khul' as a unilateral divorce initiated by the wife (Sonneveld and Stiles 2016), my fieldwork shows that the majority of Muslim religious leaders in Germany still support a religious interpretation of $k h u l^{\prime}$ that denies women the right to initiate

\footnotetext{
54 Abul al-Abd, interview with author, Berlin, April 2015.
}

55 Abu Jasser, interview with author, Berlin, June 2015. 
judicial khul'. As a result, many Muslim women in Germany today cannot end their marriages if their husbands refuse to accept a divorce.

Based on my fieldwork, I have found that Muslim religious leaders have two different approaches to khul' that is initiated by women without the husband's consent; I call one approach conservative, and the other pragmatic. Conservatives argue that khul' without the husband's consent conflicts with shari'a. They see khul' from what I have described as a traditional, patriarchal perspective, and regard women as incapable of making critical decisions. In their view, if they were to grant women the right to obtain $\mathrm{khul}^{\prime}$ in a manner equivalent to the husband's right to talāq, women would be encouraged to reject their customs and traditions, thus undermining the Muslim community. Many conservative religious leaders who were educated at al-Azhar reject the concept of khul' as a unilateral divorce without the consent of the husband, despite the fact that al-Azhar approved of khul' as a unilateral divorce in 2000.

By contrast, pragmatists maintain that a husband's agreement is not an essential prerequisite for the dissolution of a marriage. Based on Muslim minority jurisprudence, figh al-aqalliyyāt al-Muslima, pragmatists open the door for judicial khul' without the husband's consent. They argue that local imams and Islamic leaders are entitled to perform the role of a Muslim judge ( $q \bar{a} d \bar{\imath})$ if a husband refuses to accept a khul'. However, pragmatists face considerable challenges. Even if they approve of khul' without husband's consent, they still must deal with a number of legal and social constraints. If judicial khul' is to be practiced in Germany, it will require social acceptance by fellow Muslim leaders. Proponents of judicial $\mathrm{khul}^{\prime}$ must also overcome several obstacles, including the prospect of creating tension and conflict with the official German legal system, the lack of any authorized $q \bar{a} d \bar{l}$, the absence of a mechanism to compel a husband to accept khul' decisions, and clan leaders who see judicial khul' as a dangerous threat to their clan stability and even existence.

Conservatives and pragmatists have different interpretations of Islamic religious texts and tradition. The issue of khul' in Germany is further complicated by the absence of a central Islamic authority and of clear religious guidelines about the options available when a nikạh fails.

\section{References}

Al-Sharmani, Mulki. 2008. Recent Reforms in Personal Status Laws and Women's Empowerment: Family Courts in Egypt. Cairo: American University in Cairo, Social Research Center.

Ali, Ahmed. 1993. Al-Qur'an. Princeton, NJ: Princeton University Press. 
Augsberg, Ino and Stefan Korioth. 2016. "The Interplay Between State Law and Religious Law in Germany." In Rossella Bottoni, Rinaldo Cristofori, and Silvio Ferrari (eds.), Religious Rules, State Law, and Normative Pluralism - A Comparative Overview, 175-92. Switzerland: Springer Science and Business Media.

Abbasi, Muhammad Zubair. 2017. "Judicial Ijtihād as a Tool for Legal Reform: Extending Women's Right to Divorce under Islamic Law in Pakistan." Islamic Law and Society 24 (4), 384-411.

Bano, Samia. 2008. "In Pursuit of Religious and Legal Diversity: A Response to the Archbishop of Canterbury and the 'Shari'a Debate' in Britain." Ecclesiastical Law Journal 10 (3), 283-309.

Bernard, Russell. 2006. Research Methods in Anthropology: Qualitative and Quantitative Approaches. 4th ed., Lanham: Altamira Press.

Bowen, John R. 2016. On British Islam: Religion, Law, and Everyday Practice in Sharia Councils. Princeton, NJ: Princeton University Press.

Bowen, John R. 2012. A new anthropology of Islam. Cambridge: Cambridge University Press.

Carlisle, Jessica. 2008. "From Behind the Door: A Damascus Court Copes with an Alleged out of Court Marriage." In Barbara Drieskens (ed.), Les métamorphoses du mariage au Moyen-Orient, 59-74. Beirut: Presses de l'Ifpo.

Cohn, E.J. 1969 "Benefits of a Limping Marriage." The Modern Law Review 32 (5), $577-79$.

Fournier, Pascale and Pascal McDougall. 2013. "False Jurisdictions? A Revisionist Take on Customary (Religious) Law in Germany." Texas International Law Journal 48 (3), 435-63.

Ifzal, Muhammad and Salman Farooq. 2014. "Khul'(Redemption) in Islamic Law and Its Practice in Pakistani Courts, A Legal Critical Analysis." Mediterranean Journal of Social Sciences, 5 (3), 290-97.

Jaraba, Mahmoud. 2016. "Paralleljustiz' in Berlin's Mhallamī Community in View of Predominately Customary Mechanisms." Zeitschrift für Recht und Islam (8), 225-38.

Korteweg, Anna, and Jennifer Selby (eds.). 2012. Debating Sharia: Islam, Gender Politics, and Family Law Arbitration. Toronto: University of Toronto Press.

Kamp, Melanie. 2008. "Prayer Leader, Counselor, Teacher, Social Worker, and Public Relations Officer: On the Roles and Functions of Imams in Germany." In Ala AlHamarneh and Jörn Thielmann (eds.), Islam and Muslims in Germany, 133-6o. Leiden, Boston: Brill.

Keshavjee, Mohamed M. 2013. Islam, Shari'a and Alternative Dispute Resolution: Mechanisms for Legal Redress in the Muslim Community. London: I.B.Tauris.

Khir, Bustami. 2006. "The Right of Women to No-fault Divorce in Islam and its Application by British Muslims." Islam and Christian-Muslim Relations 17 (3), 295-306. 
Kruiniger, Pauline. 2015. Islamic divorces in Europe: Bridging the gap between European and Islamic legal orders. The Hague: Eleven International Publishing.

Manea, Elham. 2016. Women and Shari'a Law. London: I.B.Tauris.

Martin, Richard C. 2004. Encyclopedia of Islam and the Muslim World. New York, London: Macmillan Reference USA.

Probert, Rebecca. 2011. Family law in England and Wales. Alphen aan den Rijn, The Netherlands: Wolters Kluwer/Kluwer Law International.

Quick, Abdul Hakim. 2008. "Al-Mu'allaqa: The Muslim Woman between Divorce and Real Marriage." Journal of Islamic Law 3 (1), 27-40.

Rastin-Tehrani, Kabeh and Nadjma Yassari. 2012. "Max Planck Manual on Family Law in Afghanistan.” 2nd ed., Germany: Max Planck Institute for Comparative Public Law and International Law and Max Planck Institute for Comparative and International Private Law. <https://www.mpipriv.de/files/pdf3/max_planck_manual_on_afghan_ family_law_english.pdf $>$.

Robbers, Gerhard. 2013. Religion and Law in Germany. 2nd ed., London: Kluwer Law International.

Rohe, Mathias. 2008. "Religious Freedom and the Application of Islamic Religious Provisions." In Ala Al-Hamarneh and Jörn Thielmann (eds.), Islam and Muslims in Germany, 52-81, Leiden, Boston: Brill.

Rohe, Mathias and Mahmoud Jaraba. 2015. "Paralleljustiz: Eine Studie im Auftrag des Landes Berlin, vertreten durch die Senatsverwaltung für Justiz und Verbraucherschutz." Berlin: Senatsverwaltung für Justiz und Verbraucherschutz. <https://www.berlin.de/ sen/justva/_assets/gesamtstudie-paralleljustiz.pdf>.

Sonneveld, Nadia. 2012. Khul' Divorce in Egypt: Public Debates, Judicial Practices, and Everyday Life. Cairo and New York: American University in Cairo Press and Oxford University Press.

Sonneveld, Nadia and Erin Stiles. 2016. "Divorce and Custody: Contemporary Practices: khul.” In Suad Jospeh (ed.), Encyclopedia of Women \& Islamic Cultures. Leiden: Brill. Sonneveld, Nadia and Monika Lindbekk. 2015. "A Revolution in Muslim Family Law? Egypt's Pre- and Post-Revolutionary Period (2011-2013) Compared." New Middle Eastern Studies, 5, 1-19. <http://www.brismes.ac.uk/nmes/archives/1409>.

Stichs, Anja. 2016. "Wie viele Muslime Leben in Deutschland? Eine Hochrechnung über die Anzahl der Muslime in Deutschland zum Stand 31. Dezember 2015." Working Paper 71, Nürnberg: Bundesamt für Migration und Flüchtlinge.

Tucker, Judith E. 2008. Women, Family, and Gender in Islamic Law: Themes in Islamic Law 3. Cambridge: Cambridge University Press.

USAID. 2014. "Iraq Access to Justice Program: Values of Access to Justice and Unregistered Marriage" <http://pdf.usaid.gov/pdf_docs/PAooK2Z4.pdf>.

Van Eijk, Esther. 2016. Family Law in Syria: Patriarchy, Pluralism and Personal Status Codes, Library of Islamic law 7 , London: I.B.Tauris. 
Welchman, Lynn. 2007. Women and Muslim Family Laws in Arab States: A Comparative Overview of Textual Development and Advocacy. Amsterdam: Amsterdam University Press.

Woodman, Gordon R. 1991. "The Alternative Law of Alternative Dispute Resolution." Les Cahiers de droit 32 (1), 3-31.

Yilmaz, Ihsan. 2003. "Muslim Alternative Dispute Resolution and Neo-Ijtihad in England." Alternatives: Turkish Journal of International Relations 2 (1), 117-39.

Zahalka, Iyad. 2016. Sharia in the Modern Era. Cambridge: Cambridge University Press. 